\title{
Böyük verilənlərdə anomaliyaların aşkarlanması üçün çoxkriteriyalı optimallaşdırma üsulu
}

\author{
Rasim Oliquliyev ${ }^{1}$, Ramiz Alıquliyev ${ }^{2}$, Yadigar İmamverdiyev ${ }^{3}$, Fərqanə Abdullayeva ${ }^{4}$ \\ 1,2,3,4 AMEA İnformasiya Texnologiyaları İnstitutu, Bak1, Azərbaycan \\ ${ }^{1}$ rasimescience.az, ${ }^{2}$ r.aliguliyevegmail.com, ${ }^{3}$ yadigar@iit.science.az, ${ }^{4} a$ farqana@mail.ru
}

\begin{abstract}
Xülasə- anomaliyaların aşkarlanmasında klasterloşmə üsullarının tətbiqi effektiv yanaşmalardan hesab edilir. Məşhur k-orta və digər klassik klasterləşmə alqoritmlərində klasterin ilkin mərkəzinin seçilməsi və lokal optimumun tapılması əsas problemlərdən biridir və anomaliyaların aşkarlanmasında dəqiq nəticələr əldə etməyə imkan vermir. Məqalədə anomaliyaların aşkarlanmasında dəqiqliyi artırmaq üçün PSO (particle swarm optimization) və k-orta alqoritmlərinin birləşməsinə əsaslanan yeni çəkili klasterləşmə üsulu təklif edilmişdir. Təklif edilmiş üsul Yahoo! S5 verilənlər bazası üzərində test edilmişdir və alınmış nəticələrin k-orta alqoritmi ilə müqayisəli təhlili aparılmışdır. Eksperimentlərin nəticəsi göstərir ki, təklif edilmiş üsul k-means alqoritmi ilə müqayisədə daha dayanıqlıdır və dəqiq nəticələr əldə etməyə imkan verir.
\end{abstract}

Açar sözlər - sürü intellektino osaslanan optimallaşdırma üsulu (PSO); verilonlorin klasterloşmosi; klaster morkəzi; k-orta klasterloşmo üsulu

\section{GiRIŞ}

Verilənlərin klasterləşməsi öyrədilməyən klassifikasiya üsuludur, məqsədi verilənlər çoxluğunu verilənlər obyektləri arasındakı yaxınlığa görə klasterlərə bölməkdir. Klaster analizi verilənlərin analizi, obrazların tanınması, maşın təlimi, şəkil seqmentləşdirilməsi, neyron hesablamaları və digər elm sahələrinin mühüm vasitəsinə çevrilmişdir. Klasterləşmə alqoritminin məqsədi klasterlər arasındakı məsafəni maksimallaşdırmaq və klaster daxilindəki məsafəni minimallaşdırmaqdır.

Məşhur k-orta (k-means) alqoritmi bir çox praktik klasterləşmə məsələlərinə tətbiq edilmişdir [1, 2]. Bu üsulun məqsədi verilənlər çoxluğunu avtomatik olaraq $\mathrm{k}$ sayda qrupa bölməkdir. K-orta alqoritmi sürətli və effektiv nəticələr generasiya edə bilir. Sadə k-means alqoritmində klasterləşmə hər bir nöqtə ilə bu nöqtəyə ən yaxın olan mərkəz arasındakı orta kvadratik məsafə minimallaşdırılmaqla həyata keçirilir. Korta məşhur alqoritm olduğuna baxmayaraq bu alqoritmin çox sayda çatışmazlıqları vardır. K-orta alqoritmi ilkin klaster mərkəzinin seçilməsindən ciddi asılıdır və klaster mərkəzlərinin əvvəlcədən təyin olunmasını tələb edir. K-means alqoritminin məqsəd funksiyası qabarıq olmadığı üçün bu alqoritmin çox sayda lokal minimum nöqtələri vardır. K-means alqoritminin malik olduğu bu tip problemləri aradan qaldırmaq üçün təkamül alqoritmlərindən istifadə edirlər [3]. PSO təkamül alqoritmlərindən biridir, sürünün təfəkkürünə və sosial davranışına əsaslanır.

Odəbiyyatların analizi göstərir ki, PSO əsasında klasterləşmə mövcud klasterləşmə üsulları ilə müqayisədə daha yüksək nəticələr əldə etməyə imkan verir [4].

PSO əsasında təklif olunan mövcud klasterləşmə alqoritmlərinin bir-birindən fərqi onların məqsəd funksiyalarındadır. [3]-də PSO alqoritmini tətbiq etməklə verilənlərin klasterləşməsini təmin edən üsul təklif edilir. Burada aparılan eksperimentlərdən aydın görünür ki, kriteriyalara çəki əmsallarının verilməməsi səbəbindən instansiyaların səhv identifikasiya edilməsinə çox yol verilmişdir.

Mövcud alqoritmlərdə verilənlərin klasterləşməsi üçün minimallaşdırılacaq kriteriyaların çəkisi eyni götürüldüyündən, məqsəd funksiyasının daha optimal olmasını tənzimləmək mümkün olmur. $\mathrm{Bu}$ səbəbdən verilənlərin klasterləşməsi prosesində kriteriyaların vaciblik dərəcəsini göstərmək üçün onlara müvafiq çəki əmsalları verilməlidir [5]. Burada çəki əmsalları verilənlərin klasterləşməsi prosesində kriteriyaların vacibliyini göstərmək üçün istifadə olunur. Kriteriyalara çəkilərin verilməsi daha yaxşı optimal həll tapmağa imkan verir.

Təqdim olunan məqalədə verilənlərin klasterləşməsinin yuxarıdakı problemlərini (klasterləşmə dəqiqliyinin yüksəldilməsi, çox sayda lokal minimum nöqtələrinin olması, klaster mərkəzlərinin əvvəlcədən təyin olunmas1) aradan qaldırmaq məqsədi ilə çəkili PSO alqoritmi əsasında qurulmuş çoxkriteriyalı optimallaşdırma üsulu təklif edilir. Üsulda klaster daxili məsafənin minimallaşdırılması və klasterlər arasındakı məsafənin maksimallaşdırılması optimallaşdırma kriteriyaları kimi seçilmişdir. İşin əsas yeniliklərinə aşağıdakılar aiddir:

- Bulud mühitində baş verən anomaliyaların çəkili aşkarlanması üsulu təklif olunur. Burada optimallaşdırma məsələsi iki kriteriyanın minimallaşdırılması hesabına təmin olunur. Üsul klaster daxili məsafənin və klasterlər arasındakı məsafələrin cəminin minimallaşdırılmasını məqsəd funksiyası kimi istifadə etmişdir.

- Təklif edilmiş üsula əsasən verilənlərin klasterləşməsi üçün PSO alqoritmi qurulur. 


\section{"Informasiya tohlükosizliyinin aktual problemlori” \\ III respublika elmi-praktiki seminarı, 08 dekabr 2017-ci il}

- Təklif edilmiş üsulun imkanları Matlab proqram paketində qiymətləndirilir.

- Standart PSO alqoritminin istənilən ölçülü verilənləri klasterləşdirə bilməsi imkanı nümayiş etdirilir;

- PSO alqoritminə əsaslanan yeni klasterləşmə alqoritmi təklif edilir. Burada ilkin sürünü formalaşdırmaq üçün k-orta alqoritmi istifadə edilir.

\section{SÜRÜ INTELLEKTINĐ ЭSASLANAN OPTIMALLAŞDIRMA ÜSULU}

Sürü intellektinə əsaslanan optimallaşdırma alqoritmi (PSO) 1995-ci ildə Eberhart və Kennedy tərəfindən yaradılmışdır, popalyasiya tipli stoxastik axtarış prosesi alqoritmidir, quş sürülərinin sosial davranışına əsasən modelləşdirilmişdir [6, 7]. Alqoritmin əsasını hissəciklərin populyasiyası təşkil edir. $\mathrm{Bu}$ hissəciklərin hər biri optimallaşdırma məsələsinin mümkün həllini göstərir.

PSO alqoritmində sürü optimallaşdırma məsələsinə bir neçə mümkün həllər generasiya edir. Bu mümkün həllərin hər biri hissəcik adlanır. PSO alqoritminin məqsədi qoyulmuş məqsəd funksiyasını (fitness, objective) daha yaxşı ödəyən hissəciyi (həlli) tapmaqdir.

Hər bir hissəcik $N_{d}$ ölçülü fəzada bir pozisiyanı göstərir və çoxölçülü axtarış fəzasında öz pozisiyasını aşağıdakılara əsasən tənzimləyərək hərəkət edir (uçur):

- Hissəciyin özünün ən yaxşı pozisiyası (best position);

- Həmin hissəciyin qonşularının ən yaxşı pozisiyası.

Hər bir $i$-ci hissəcik aşağıdakılardan ibarət olur:

- $\quad x_{i}$-hissəciyin cari pozisiyası;

- $\quad v_{i}$-hissəciyin cari sürəti;

- $y_{i}$-hissəciyin personal ən yaxşı pozisiyası.

Hissəciyin pozisiyası aşağıdakı parametrlərə əsasən tənzimlənir:

$$
\begin{aligned}
& v_{i, k}(t+1)=\omega v_{i k}(t)+c_{1} r_{1 k}(t)\left(\overrightarrow{y_{i k}}(t)-x_{i k}(t)\right)+ \\
&+c_{2} r_{2 k}(t)\left(\overrightarrow{y_{k}}(t)-x_{i k}(t)\right) \\
& x_{i}(t+1)=x_{i}(t)+v_{i}(t+1)
\end{aligned}
$$

burada, $\omega$ - inersiya omsalidır $(\omega=0.7298), c_{1}$ və $c_{2}$ sürətləndirmə sabitləridir, $r_{1, j}(t), r_{2, j}(t) \sim U, k=1, \ldots, N_{d}$.

$i$-ci hissəciyin personal ən yaxşı pozisiyası aşağıdakı kimi

$$
y_{i}(t+1)=\left\{\begin{array}{cc}
y_{i}(t) & f\left(x_{i}(t+1)\right) \geq f\left(y_{i}(t)\right) \\
x_{i}(t+1) & f\left(x_{i}(t+1)\right)<f\left(y_{i}(t)\right)
\end{array}\right.
$$

\section{KLASTERLЭŞMӘ MəSЭLOSININ QOYULUȘU}

$R^{n}$ fəzasında klasterləşmə məsələsi aşağıdakı kimi qoyulur: $n$ nöqtədən ibarət $x_{1}, x_{2}, \ldots, x_{n}$ nöqtələr çoxluğunun yaxınlıq meyarına görə $k$ (məlum sabit ədəd) sayda $G_{1}, G_{2}, \ldots, G_{k}$ çoxluğuna bölünməsi həyata keçirilir.

Burada bölünmə zamanı aşağıdakı şərtlər ödənməlidir:

1) $G_{i} \neq \varnothing, \quad i=1,2, \ldots, k$; (4)

2) $G_{i} \cap G_{j}=\varnothing, i, j=1,2, \ldots, k ; i \neq j$ (5)

3) $\bigcup_{i=1}^{k} G_{i}=\left\{x_{1}, x_{2}, \ldots, x_{n}\right\}$ (6)

Klasterləşmə bir-birinə yaxın obyektlərin eyni klasterə təyin edilməsini təmin etməklə obyektlər çoxluğunu bir neçə klasterdə qruplaşdıran prosesdir. K-orta alqoritmi ən məşhur və geniş istifadə olunan klasterləşmə üsuludur. K-orta alqoritmi hər bir nöqtədən ona ən yaxın klaster mərkəzinə qədər olan məsafənin kvadratının cəminin minimum olduğu $C_{1}, C_{2}, \ldots, C_{k}$ klasterlər mərkəzlərini tapmağa cəhd edir (7).

$$
D=\sum_{i=1}^{n}[\underbrace{\min }_{k=1,2, \ldots, K} d\left(x_{i}, c_{k}\right)]^{2}
$$

burada d hər hansı bir məsafə funksiyasıdır. Təqdim olunan məqalədə bu funksiya Evklid götürülmüşdür.

Onənəvi k-orta alqoritmini aşağıdakı addımlar təşkil edir:

Addım 1. $k$ sayda klasterlərin təyin edilməsi və hər bir klaster üçün $\left(C_{1}^{(0)}, C_{2}^{(0)}, \ldots, C_{k}^{(0)}\right)$ mərkəzin elan edilməsi. Hər bir klaster mərkəzi $m$ ölçülü vektordur məsələn, $C_{i}^{(0)}=\left\{C_{i 1}^{(0)}, C_{i 2}^{(0)}, \ldots, C_{i m}^{(0)}\right\}$.

Addım 2. $i$-ci verilənlər çoxluğu ilə ( $m$ ölçülü fəzada nöqtə) $k$-c1 klaster mərkəzi arasında $d_{k i}^{(t-1)}$ məsafəsinin hesablanması. Məsafə meyarı kimi (8) düsturunda verilmiş Evklid məsafəsi istifadə edilmişdir.

$$
d_{k i}^{(t-1)}=\left\|x_{i}-C_{k}^{(t-1)}\right\|=\sqrt{\sum_{j=1}^{m}\left(x_{i j}-C_{k j}^{(t-1)}\right)^{2}}
$$

Addım 3. Hər bir $x_{i}$ verilənlər obyektinin ən yaxın $C_{k}$ klaster mərkəzinə təyin edilməsi.

Addım 4. Hər bir $C_{k}^{(t)}$ klaster morkəzinin ona daxil olan bütün $x_{i}$ nöqtələrinin ortalama qiymətini hesablayan (9) düsturu vasitəsi ilə yenilənməsi.

$$
C_{k}^{(t)}=\frac{\sum_{x_{i} \in k} x_{i}}{n_{k}}
$$

burada $n_{k} \quad k$-cı klasterə daxil olan nöqtələrin sayıdır. 


\section{"Informasiya tohlükosizliyinin aktual problemlori” \\ III respublika elmi-praktiki seminarı, 08 dekabr 2017-ci il}

Addım 5. (7) düsturu vasitəsi ilə klasterdaxili $D$ məsafənin hesablanmasi.

Addım 6. Ogər $D$-nin qiyməti qənaətbəxşdirsə yekun klaster mərkəzlərinin seçilməsi. Oks halda $t=t+1 \quad$-ci iterasiyaya keçid edərək 2-ci addıma qayıtmaq.

\section{PSO KLASTERLəŞMӘSI ÜÇÜN TӘKLIF EDILӘN OPTIMALLAŞDIRMA FUNKSIYASI}

PSO klasterləşmə alqoritmində hər bir $Y_{i}=\left(y_{1}, y_{2}, \ldots, y_{k}\right)$ həlli (particle) $k$ sayda sinfin mərkəzlərini əks etdirir. Burada həllər sürüsü bir neçə namizəd kimi klassifikasiya olunmuş plandan ibarət olur. Optimallaşdırma alqoritmində bu namizəd kimi klassifikasiya olunmuş planlardan qoyulmuş şərti ödəyən planın seçilməsi üçün məqsəd funksiyasından istifadə edilir. $\mathrm{Bu}$ məqsədlə təqdim olunan məqalədə aşağıdakı məqsəd funksiyası təklif edilir:

$$
f=(1-\alpha) \times \sum_{i=1}^{n} \sum_{j=1}^{c}\left\|x_{i}-c_{j}\right\|+\alpha \times \sum_{k, j=1}^{c}\left\|c_{k}-c_{j}\right\| \rightarrow \min (10)
$$

Burada məqsəd (10) düsturu vasitəsi ilə verilmiş qiymətləndirmə funksiyasının aldığ 1 qiyməti minimallaşdırmaqdır. Yəni (10) funksiyasının minimum qiymətində klasterləşmənin daha effektiv aparılacağ edilir. $(1-\alpha)$ və $\alpha$ uyğun olaraq $J_{1}$ və $J_{2}$ faktorlarının çəki əmsallarıdır, $J_{1}$ və $J_{2}$ faktorlarının qiymətləndirməyə təsirini göstərir. Aparılan bir sıra eksperimentlərin nəticəsində çəki əmsalının $\alpha=0.731$ qiymətində klasterləşmənin nəticəsi nisbətən sabit və daha yaxşı olmuşdur. Bu səbəbdən məqalədə çəki əmsalının qiyməti $\alpha=0.731$ götürülmüşdür.

$f$ funksiyasının minimal qiyməti eyni sinifdə nöqtələr arasındakı məsafənin kiçik olması və siniflər arasındakı məsafənin böyük olması şərtlərini ödəyir. $f$ funksiyasının qiyməti minimum olan klassifikasiya planı on yaxşı hesab edilir.

Məqsəd funksiyasını təşkil edən iki kriteriya aşağıdakılardır.

a) Klaster daxili mosafo (inner-cluster distance) klasterin bütün nöqtələrindən onun mərkəzinə qədər olan məsafədir, alqoritmin məqsədi klaster daxili məsafəni minimallaşdırmaqdır. $\mathrm{Bu}$ kriteriya aşağıdakı düsturla hesablanır:

$$
J_{1}=(1-\alpha) \times \sum_{i=1}^{n} \sum_{j=1}^{c}\left\|x_{i}-c_{j}\right\|(11)
$$

burada, $c_{j} j$-cu klasterin mərkəzidir, $x_{i}-c_{j}$ klasterinə daxil olan nöqtələrdir.

b) Klasterlor arasındakı məsafo (inter-cluster distance) klasterlərin mərkəzləri arasında məsafədir, məqsədi klasterlər arasındakı məsafəni maksimallaşdırmaqdır. $\mathrm{Bu}$ kriteriya aşağıdakı düsturla hesablanır:

$$
J_{2}=\alpha \times \sum_{k, j=1}^{c}\left\|c_{k}-c_{j}\right\|(12)
$$

burada, $c_{k}$ və $c_{j}$ uyğun olaraq $k$-cı və $j$-cu klasterlərin mərkəzidir.

\section{ANOMALIYALARIN AŞKARLANMASI ÜÇÜN TOKLIF EDILMIŞ OPTIMALLAŞDIRMA MODELI}

Anomaliyaların aşkarlanması üçün təklif edilmiş optimallaşdırma modeli şəkil 1-də təsvir edilmişdir. Şəkildən göründüyü kimi model PSO və ənənəvi k-orta alqoritmlərinin birləşdirilməsi ideyasına əsaslanır.

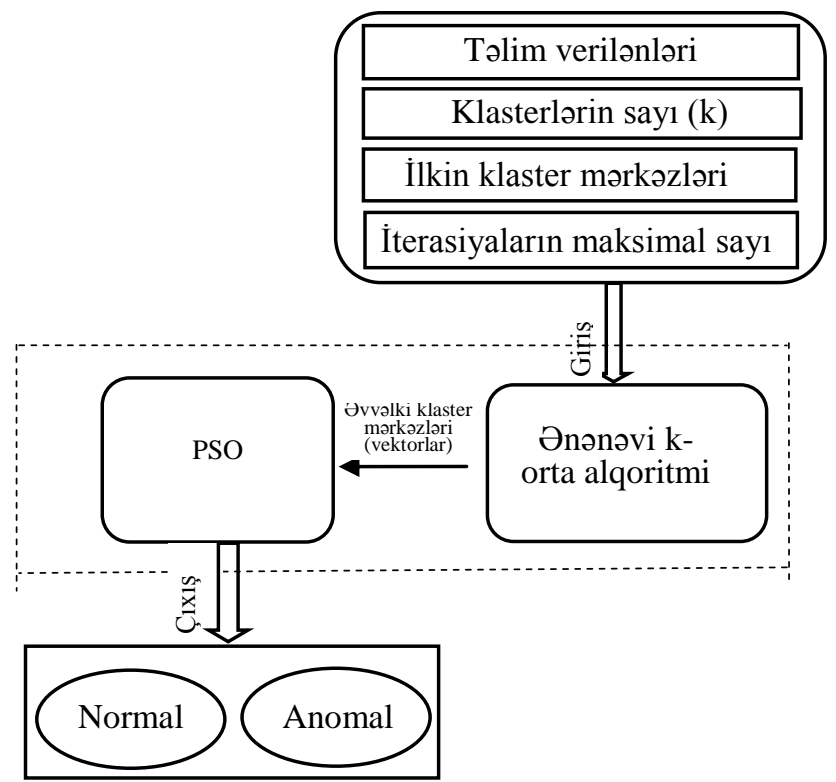

Şəkil 1. Anomaliyaların aşkarlanması üçün optimallaşdırma modeli

$\mathrm{Bu}$ struktura uyğun olaraq anomaliyaların aşkarlanması üçün PSO əsasında optimallaşdırma məsələsinin alqoritmi aşağıdakı addımlardan ibarətdir:

Addım 1. Populyasiyanın ölçüsünün $m, \quad c_{1}$ və $c_{2}$ sürətləndirmə əmsallarının, iterasiyaların sayının, kiçik təsadüfi pozisiyalardan ibarət ilkin $x_{p}$ həllər populyasiyasının, inersiya əmsalının ( $\omega$ ), klasterlərin sayının $k, n$ nöqtədən ibarət verilənlər çoxluğunun daxil edilməsi.

Addım 2. k-orta alqoritmi vasitəsi ilə populyasiyanın hər bir hissəciyi üçün aşağıdakı addımların yerinə yetirilməsi:

1) (8) düsturundan istifadə etməklə $p$-ci klaster mərkəzi (həll) ilə $i$-ci nöqtə arasında $d_{p i}$ Evklid məsafəsinin hesablanmasi.

2) Hər bir $x_{i}$ nöqtəsinin ən yaxın $X_{p}$ klaster mərkəzinə təyin edilmosi.

Addım 3. Verilənlər obyektlərini minimum məsafə kriteriyasına əsasən qruplaşdırdıqdan sonra, yəni klasterlərin sinifləri tapıldıqdan sonra klasterləşmənın dəqiqliyini artırmaq 


\section{“Informasiya tohlükosizliyinin aktual problemlori” \\ III respublika elmi-praktiki seminarı, 08 dekabr 2017-ci il}

üçün təklif edilmiş (10) düsturu vasitəsi ilə məqsəd funksiyasının qiymətləndirilməsi.

Addım 4. Məqsəd funksiyasının qiymətinə görə qiymətləndirmənin nəticəsinin həllin əvvalki $P_{\text {best }}$ ən yaxş1 qiyməti ilə müqayisə edilməsi. Ogər cari pozisiya qiyməti (klaster mərkəzinin mövqeyi) $P_{b e s t}$-dən yaxşı olarsa, cari pozisiyan $P_{\text {best }}$-in yerinə təyin edilməsi, əks halda $P_{b e s t}$-in əvvəlki qiymətinə bərabər saxlanması. $\mathrm{Bu}$ proses populyasiyanın hər bir həllinə tətbiq olunur.

Addım 5. $P_{\text {best }}$ yeniləndikdən sonra məqsəd funksiyasının ən yaxşı qiymətinin (məqsəd funksiyasının qiyməti minimum olanın) seçilməsi və onun $G_{b e s t}$ kimi təyin edilməsi. $G_{b e s t}$ $k \times m$ ölçülü vahid həlldir (particle). $k$ klasterlərin sayıdır, verilənlər bazasını bölmək üçün təyin edilmişdir.

Addım 6. Hər bir həllin sürəti və pozisiyası uyğun olaraq (1) və (2) düsturları vasitəsi ilə yenilənir.

Addım 7. Konvergentlik kriteriyasının yoxlanması. Bu kriteriyalar kimi məqsəd funksiyasının ən yaxşı qiyməti və ya iterasiyaların maksimal sayı götürülür. Đgər konvergentlik kriteriyası ödənilibsə $G_{\text {best }}$ qiyməti optimal klaster mərkəzi kimi qeyd olunur, əks halda iterasiyaların sayı $t=t+1$ addım artırılır və addım 2-yə qayıdılır.

\section{EKSPERIMENTLOR}

$\mathrm{Bu}$ bölmədə effektivliyi qiymətləndirmək üçün təklif edilmiş üsulun və k-means alqoritminin Yahoo! S5 real verilənlər bazası üzərində klasterləşmə nəticələrinin müqayisəli analizi aparılır. PSO əsasında klasterləşmə alqoritmində sürətləndirmə əmsalı $\mathrm{C}_{1}=\mathrm{C}_{2}=1.4962$ götürülmüşdür.

Test prosesində populyasiyanın ölçüsü 50 götürülərək məqsəd funksiyasının qiyməti (10) düsturuna əsasən hesablanmışdır.

İstifadə edilmiş A1Benchmark Yahoo! S5 verilənlər bazasının real_2.csv faylı 1440 sətirdən ibarətdir. Bu bazanın əlamətlər vektorunu vaxt qeydiyyatı və qiymət kimi iki parametr təşkil edir və burada həmçinin əlamətin normal və ya anomal olduğu da göstərilir. Yəni baza təsnif olunmuş bazadır.

Eksperimentlorin aparılması üçün Yahoo! S5 bazasından ümumi olaraq 84 nöqto götürülmüşdür, onlardan 68-i normal 16-s1 anomal nöqtələrdir. $\mathrm{Bu}$ baza üzərində aparılan eksperimentlərdə k-means alqoritminin nəticəsinə görə verilənlərin 79-u normal 5-i anomal kimi identifikasiya edilmişdir. Burada 11 nöqtə yanlış identifikasiya edilmişdir.

Təklif edilmiş PSO alqoritmində isə ümumi verilənlərin 72si normal 12-si anomal kimi identifikasiya edilmişdir. Bu alqoritmdə 4 nöqtə yanlış identifikasiya edilmişdir.

Klasterləşmənin effektivliyi dörd metrika üzərində qiymətləndirilmişdir: Dunn's index, Silhouette index, Purity index, Entropy Index (cədvəl 1) [8, 9, 10].

\begin{tabular}{|c|c|c|c|c|c|c|c|c|c|}
\hline & 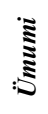 & 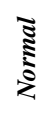 & 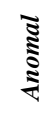 & ڤ & है & 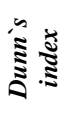 & : & 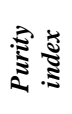 & 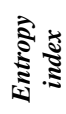 \\
\hline $\begin{array}{c}\mathrm{K}- \\
\text { means }\end{array}$ & 84 & 79 & 5 & 11 & - & 0,05 & 0,39 & 0,87 & 0,58 \\
\hline PSO & 84 & 72 & 12 & 4 & - & 0,38 & 0,87 & 0,95 & 0,31 \\
\hline Real & 84 & 68 & 16 & - & - & - & - & - & - \\
\hline
\end{tabular}

CəDVəl 1. $\alpha=0.731$ QIYMəTINDə PSO ALQORITMININ KLASTERLəŞMə NəTICəLəRI

Burada klasterləşmənin qiymətləndirilmə metrikalarına görə k-means alqoritminin Dunn indeksi 0,0510, PSO alqoritminin Dunn indeksi isə 0,3847 təşkil etmişdir. Qeyd edək ki, Dunn indeksi nə qədər böyük olsa alqoritm bir o qədər effektiv hesab edilir. Silhouette indeksinə görə k-means alqoritmi 0,3899 , PSO alqoritmi 0,8722 olmuşdur. Təklif edilmiş üsuldan digər metrikalar üzrə də yaxşı nəticələr əldə edilmişdir. Belə ki, Purity indeksinə görə k-means alqoritmi 0,8690 , PSO alqoritmi 0,9524 qiymət almışdır. Entropiyanın hesablanması zamanı isə k-means alqoritminin entropiyası 0,5821, PSO alqoritminin entropiyası isə 0,3096 təşkil etmiş̧ir. Klasterləşmə məsələsində entropiyanın az olması üsulun daha effektiv olduğunu göstərir.

Təklif edilən PSO alqoritminin iterasiyalarının say 200 götürülmüşdür və alınmış nəticələr get-gedə yaxşılaşaraq optimal həll (BestCost) tapılmışdır (şəkil 2).

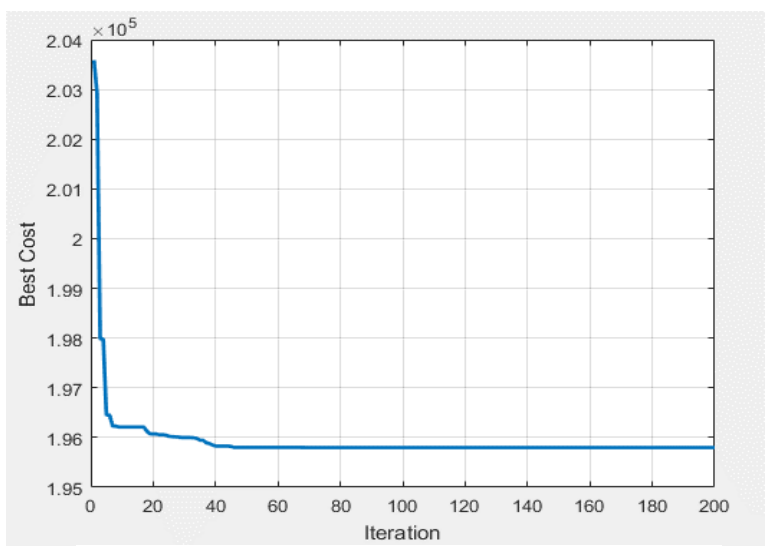

Şəkil 2. PSO əsasında optimal həll dinamikası

\section{Nəтісə}

Araşdırmalar göstərir ki, PSO alqoritmi, PSO-nun modifikasiyaları və onun müxtəlif alqoritmlərlə hibridləşdirilməsi optimallaşdırma məsələsinin həllində effektivlik və dəqiqlik baxımından çox yaxşı nəticələr verir. Bu alqoritmin verilənlərin klasterləşməsi məsələsinə tətbiqi klasterlərin dəqiq yaradılmasına və verilənlərin dəqiq proqnoz və klasterləşməsinə imkan verir. Məqalədə verilənlərin 


\section{"Informasiya tohlükosizliyinin aktual problemlori” \\ III respublika elmi-praktiki seminarı, 08 dekabr 2017-ci il}

klasterləşməsi üçün PSO alqoritminə əsaslanan çoxkriteriyalı optimallaşdırma metodu təklif edilmişdir. Metodun k-orta alqoritmi ilə müqayisəli dəqiqliyi Yahoo! S5 verilənlər bazas1 üzərində test edilmişdir. Eksperimentlərin nəticəsi PSO əsasında klasterləşmə üsulunun k-orta alqoritmindən daha yaxş1 olduğunu göstərmişdir.

\section{MINNOTDARLIQ}

$\mathrm{Bu}$ iş Azərbaycan Respublikasının Prezidenti yanında Elmin İnkişafı Fondunun maliyyə yardımı ilə yerinə yetirilmişdirQrant № EIF-KETPL-2-2015-1(25)-56/05/1

\section{ӘDӘBIYYYAT}

[1] S.Z. Selim, M.A. Ismail, "K-means-type algorithms: A generalized convergence theorem and characterization of local optimality," IEEE Transactions on Pattern Analysis and Machine Intelligence, 1984, vol 6, no. 1 , pp. 81-87.

[2] H.T. Sarma, P. Viswanath, B.E. Reddy, "A hybrid approach to speed-up the k-means clustering method," International Journal of Machine Learning and Cybernetics, 2013, vol 4, no. 2, pp. 107-117.

[3] S. Rana, S. Jasola, R. Kumar, "A boundary restricted adaptive particle swarm optimization for data clustering," International Journal of Machine Learning and Cybernetics, 2013, vol. 4, no. 4, pp 391-400.

[4] R.J. Kuo, M.J. Wang, T.W. Huang, "An application of particle swarm optimization algorithm to clustering analysis," Soft Computing, 2011, vol. 15, no. 3, pp. 533-542.

[5] R.M. Alguliyev, Y.N. Imamverdiyev, F.C. Abdullayeva, "Multıcriterı optımization method for load balancing in cloud computıng," Problems of information technology, 2017, № 2, pp. 3-15.

[6] J. Kennedy, R. Eberhart, "Particle Swarm Optimization," Proc. of the 1EEE International Conference on Neural Networks, 1995, vol. 4, pp. 1942-1948.

[7] R. Eberhart, Y. Shi, J. Kennedy, "Swarm Intelligence," 1st edition, 2002,512 p.
[8] J.C. Dunn, "Well Separated Clusters and Optimal Fuzzy Partitions," Journal of Cybernetics, 1974, vol. 4, no. 1, pp. 95-104.

[9] S. Saitta, B. Raphael, F.C. Smith, "A Bounded Index for Cluster Validity," Proc. of the International Workshop on Machine Learning and Data Mining in Pattern Recognition, 2007, pp. 174-187.

[10] R.M. Aliguliyev, "Performance evaluation of density-based clustering methods," Information Sciences, 2009, vol. 179, no. 20, pp. 3583-3602.

\section{MULTI-CRITERION OPTIMIZATION METHOD FOR ANOMALY DETECTION ON BIG DATA}

Rasim Alguliyev ${ }^{1}$, Ramiz Aliguliyev ${ }^{2}$, Yadigar Imamverdiyev ${ }^{3}$, Fargana Abdullayeva ${ }^{4}$ ${ }^{1,2,3,4}$ Institute of Information Technology of ANAS, Baku, Azerbaijan

${ }^{1}$ r.alguliev@gmail.com, ${ }^{2}$ r.aliguliyev@gmail.com,

3yadigar@iit.science.az, ${ }^{4}$ a_farqana@mail.ru

Abstract - The use of clustering methods in anomaly detection is considered as an effective approach. The choice of the cluster primary center and the finding of local optimum in the well-known kmeans and other classic clustering algorithms are considered as one of the major problems and do not allow to get accurate results in anomaly detection. In this paper to improve the accuracy of anomaly detection based on the combination of PSO (particle swarm optimization) and k-means algorithms, the new weighted clustering method is proposed. The proposed method is tested on Yahoo! S5 dataset and a comparative analysis of the obtained results with the kmeans algorithm is performed. The results of experiments show that the proposed method is more robust compared with the k-means algorithm and allows to get more accurate results.

Keywords - particle swarm optimization (PSO); data clustering; cluster center; $\mathrm{k}$-means 